\title{
ASSESSMENT OF PHYLLOPLANE MICRO-ORGANISM POPULATIONS IN CANTERBURY APPLE ORCHARDS
}

\author{
G.R. BAKKER ${ }^{1}$, C.M. FRAMPTON ${ }^{1}$, M.V. JASPERS ${ }^{1}$, A. STEWART $^{1}$ \\ and M. WALTER ${ }^{2}$ \\ ${ }^{1}$ Soil, Plant and Ecological Sciences Department, Lincoln University, PO Box \\ 84, Canterbury \\ ${ }^{2}$ HortResearch, Gerald Street, Lincoln \\ Corresponding author: bakkerg@lincoln.ac.nz.
}

\begin{abstract}
Micro-organism populations on the leaf surface can be an indicator of environmental health in orchards. A method was developed to detect changes in these populations in apple orchards. Firstly, the variation within orchards was investigated by sampling leaves from seven locations within four trees in spring and autumn. The population density and species richness of micro-organisms when grown on PDA showed tree and season effects $(\mathrm{P}<0.05)$ but few significant effects of locations within trees or of replicated branches. Based on these findings, the method was modified to study phylloplane micro-organism populations in nine Canterbury orchards at four times during the 1999-2000 season. The method detected an increasing population density and richness (number of recognisable taxonomic units per sample) during the season in all orchards, and higher density and richness $(\mathrm{P}<0.05)$ in unconventionally managed orchards compared with conventionally managed orchards.
\end{abstract}

Keywords: disease management systems, bacteria, fungi, yeasts.

\section{INTRODUCTION}

The effects of pesticides on the environment and consumers, has led to increasing worldwide demand for sustainable food production. In the development of sustainable crop production systems, it is essential that the effect of pesticides on non-target organisms be determined. Extensive studies have been carried out into the effects of pesticides on beneficial arthropod populations, but research into the effects on micro-organism populations has been relatively limited (Jacobsen 1997). In New Zealand, research has been initiated in apple production to develop sustainable pest and disease management systems and orchard indicators of environmental health.

The current project aims to develop methods to investigate the variation in phylloplane micro-organism populations in different New Zealand apple production systems. Micro-organism populations of the leaf surface (phylloplane microorganisms) vary in size and diversity depending on the influence of numerous biotic and abiotic factors which affect their growth and survival. These factors include leaf age, external nutrients, the interactions between populations of different microorganisms (Blakeman 1985), temperature, relative humidity, duration of leaf wetness, light intensity, wind speed and the presence of air pollutants and pesticides (Dix \& Webster 1995). Pesticides in particular, have the potential to reduce population diversity and to give competitive advantages to some species, including foliar pathogens (Bosshard et al. 1987).

Based on the factors above, considerable spatial and temporal variations can be expected between and within orchards (Hirano \& Upper 1986). Therefore, an initial study was conducted to determine the population variations between trees, locations and replicated sites within trees, and investigate seasonal variations (Study 1). After quantification of the sources of variation, the sampling method was modified and used

New Zealand Plant Protection 55:129-134 (2002) 
to study the variation between different orchard management systems (Study 2). To allow sampling of many trees in a representative number of orchards several times during a season, the method needed to be robust, but also simple enough to enable quick sampling, isolation and assessment while avoiding the introduction of variation through delayed processing.

\section{MATERIALS AND METHODS}

Sources of variation (Study 1)

During the 1998/99 season, four trees in an unsprayed eight-year old Braeburn apple orchard at Lincoln University were sampled to investigate the sources of variation for estimating phylloplane micro-organism populations. On 1 December 1998 and on 11 April 1999, samples of five leaves were picked at random across all leaf ages from each of two replicated branches on the north, east, south, west, top, middle and bottom locations of the canopies. The 5-leaf samples were placed in new plastic bags and stored at $4 \pm 2{ }^{\circ} \mathrm{C}$ for $24-72 \mathrm{~h}$ until processed. The microorganisms were then washed off the leaves by adding $20 \mathrm{ml}$ sterile phosphate buffer (6.75 g K H $2 \mathrm{PO}_{4}+8.75 \mathrm{~g} \mathrm{~K}_{2} \mathrm{HPO}_{4}+0.5 \mathrm{ml}$ Tween $20+1$ litre $\mathrm{H}_{2} \mathrm{O}$ (Morris et al. 1997)) to the original plastic bags and using a stomacher blender (Interscience BagMixer 400) for $1 \mathrm{~min}$. Aliquots of $500 \mu \mathrm{l}$ of serial dilutions of $2 \times 10^{-3}$ and $2 \times 10^{-4}$ of the suspension were spread onto three replicated agar plates and incubated for 7 days at $20 \pm 1{ }^{\circ} \mathrm{C}$, and a $12 \mathrm{~h}$ photoperiod. Potato dextrose agar (PDA, Merck) was used because it was reported to recover the widest range of filamentous fungi (Kinkel et al. 1989) as well as yeasts and many phylloplane bacteria (Goto et al. 1994). Resulting colonies were counted and classified into four groups: bacteria, smooth yeasts, Aureobasidium spp and filamentous fungi. Within each group the organisms were further classified into Recognisable Taxonomic Units (RTUs) based on their colony characteristics. The variation in population density (colony forming units (CFUs)/sample) for trees, locations, branches, seasons and replicate plates was presented per leaf, while the variation in species richness (RTUs/sample) was presented per replicated branch. All data were analysed using ANOVA (General Linear Model, Genstat for Windows, release 4.1). The relative importance of each source of variation was then determined by calculating the proportion of its sums of squares, relative to the total sums of squares, from the ANOVA tables.

Variation between orchards (Study 2)

During the 1999/2000 growing season, the population densities and richness of culturable phylloplane micro-organisms were determined in nine Canterbury Braeburn orchards. One control (unsprayed) orchard at Lincoln University, two BIO-GRO orchards (one certified at Springston; one transitional at Dunsandel), and six orchards that followed IFP (Integrated Fruit Production) guidelines, were selected. Three IFP orchards (one at Rolleston and two at Christchurch) produced for export and the other three (Christchurch, Taitapu and Lincoln) produced for the local market. The latter system allows greater pesticide usage compared to IFP guidelines for export. The selected trees were all between eight and ten years old.

All orchards were sampled at $25 \pm 4$ and $50 \pm 4$ days after full bloom (assessment 1 and 2, respectively), and at $25 \pm 4$ days before and shortly before harvest commencement (assessment 3 and 4, respectively). Based on the results of Study 1, five leaves were picked at random across all leaf ages from two opposite sides of each tree. In each orchard six trees in the centre and six along the perimeter were sampled. Leaves were stored and washed as described in Study 1. The washing suspensions were combined for the six centre and for the six perimeter trees prior to serial dilution. Aliquots $(100 \mu \mathrm{l})$ of each dilution were spread onto ten replicate PDA agar plates. Incubation, population density and richness assessments, microorganism classification and statistical analysis were conducted as described above, except that this time the species richness was presented per orchard location instead 
of per replicated branch. Analyses were carried out for individual orchard types as well as for conventional orchards (all IFP orchards) versus unconventional orchards (BIO-GRO and unsprayed).

\section{Sources of variation (Study 1)}

\section{RESULTS}

Table 1 shows the differences in populations between trees and locations for the two seasons studied. In spring, tree 4 had a significantly lower population density and lower richness than the other trees. In autumn, tree 3 had a higher population density than the other trees, and trees 1 and 3 had a greater richness than trees 2 and $4(\mathrm{P}<0.05)$. In spring, there were no differences in richness between different locations, but the population density on leaves in the south side of the trees was higher than elsewhere in the tree. In autumn there were no significant differences in density between the locations within a tree, but the richness was greater in the north, east and west than in the south side of the trees. No significant differences $(\mathrm{P}>0.05)$ were found in population density or richness between different branches or between different plates, neither in spring nor in autumn.

TABLE 1: Mean microbial population density $\left(\mathrm{CFU} \times 10^{6}\right)$ and richness (RTUs/leaf) of micro-organisms recovered for each tree and for location within trees, on 1 December 1998 and on 11 April 1999.

\begin{tabular}{lcclll}
\hline & \multicolumn{2}{c}{1 December 1998} & & \multicolumn{2}{c}{11 April 1999} \\
\cline { 2 - 3 } \cline { 5 - 5 } Location & Density & Richness & & Density & Richness \\
\hline Trees & & & & \\
Tree 1 & $1.21 \mathrm{~b}^{1}$ & $9.1 \mathrm{~b}$ & & $0.72 \mathrm{~b}$ & $8.6 \mathrm{~b}$ \\
Tree 2 & $1.07 \mathrm{~b}$ & $7.8 \mathrm{~b}$ & & $0.52 \mathrm{a}$ & $6.8 \mathrm{a}$ \\
Tree 3 & $1.21 \mathrm{~b}$ & $7.8 \mathrm{~b}$ & & $1.02 \mathrm{c}$ & $9.0 \mathrm{~b}$ \\
Tree 4 & $0.30 \mathrm{a}$ & $6.0 \mathrm{a}$ & & $0.44 \mathrm{a}$ & $6.7 \mathrm{a}$ \\
Location & & & & & \\
North & $1.04 \mathrm{a}$ & $7.4 \mathrm{a}$ & & $0.66 \mathrm{a}$ & $8.5 \mathrm{bc}$ \\
East & $0.77 \mathrm{a}$ & $7.7 \mathrm{a}$ & & $0.72 \mathrm{a}$ & $8.5 \mathrm{bc}$ \\
South & $1.64 \mathrm{~b}$ & $8.0 \mathrm{a}$ & & $0.68 \mathrm{a}$ & $6.7 \mathrm{a}$ \\
West & $0.85 \mathrm{a}$ & $8.4 \mathrm{a}$ & & $0.78 \mathrm{a}$ & $7.8 \mathrm{bc}$ \\
Top & $0.75 \mathrm{a}$ & $7.0 \mathrm{a}$ & & $0.71 \mathrm{a}$ & $7.7 \mathrm{abc}$ \\
Middle & $0.54 \mathrm{a}$ & $7.0 \mathrm{a}$ & & $0.60 \mathrm{a}$ & $7.6 \mathrm{abc}$ \\
Bottom & $1.06 \mathrm{a}$ & $8.3 \mathrm{a}$ & & $0.59 \mathrm{a}$ & $7.4 \mathrm{ab}$
\end{tabular}

${ }^{1}$ Values in a section within each column sharing the same letter do not differ significantly, ANOVA, $\mathrm{P}<0.05$

Despite a few significant spatial effects on micro-organism populations during both assessments, the source of variation (as determined by calculating the proportion of its sums of squares, relative to the total sums of squares from the ANOVA tables) showed that during spring, the source of variation for population density and richness was relatively evenly distributed over trees and locations. In autumn the location within trees did not contribute to the variation, and the greatest source of variation was in the replicated branches (Table 2). 
TABLE 2: Relative sources of variation (\%) in population density and richness of phylloplane micro-organisms recovered from apple leaves.

\begin{tabular}{lccrr}
\hline \multirow{2}{*}{ Sources of variation } & \multicolumn{2}{c}{ 1 December 1998 } & \multicolumn{2}{c}{11 April 1999 } \\
& Density & Richness & Density & Richness \\
\hline Tree & 49.3 & 37.8 & 33.6 & 3.5 \\
Location & 38.7 & 21.5 & 0.0 & 0.0 \\
Branches & n.a. ${ }^{1}$ & n.a. ${ }^{1}$ & 49.4 & 90.6 \\
Plates & 12.1 & 40.7 & 17.0 & 5.9 \\
Total & 100.0 & 100.0 & 100.0 & 100.0
\end{tabular}

${ }^{1}$ Due to experimental error, the source of variation for replication of samples could be calculated only in autumn.

Variation between orchards (Study 2)

Overall, there were no significant differences $(\mathrm{P}>0.05)$ in population density and richness of total culturable phylloplane micro-organisms between centre and perimeter of orchards during any of the assessments. Analysis of variance of the data for the population density for the four main organism groups showed significant orchard and season effects. Overall, bacteria counts were least affected by assessment time and orchard (i.e. bacterial counts between assessment times and orchards were generally of similar magnitude), whereas the numbers of Aureobasidium spp differed most between assessment times and orchards (Table 3).

TABLE 3: Probability values of season and orchard effects and the season $x$ orchard interaction on population densities, calculated using ANOVA for the individual micro-organism groups.

\begin{tabular}{lcccc}
\hline Factor & Bacteria & Smooth yeasts & $\begin{array}{c}\text { Aureobasidium } \\
\text { spp. }\end{array}$ & Filamentous fungi \\
\hline Assessment time & 0.246 & 0.000 & 0.000 & 0.000 \\
Orchard & 0.538 & 0.017 & 0.000 & 0.078 \\
Assessment x orchard & 0.514 & 0.001 & 0.000 & 0.241 \\
\hline
\end{tabular}

Table 4 shows the seasonal differences in populations between orchard management types studied. During assessment 1, the 'IFP local market' orchards had a significantly lower richness than the BIO-GRO or unsprayed orchards, but not significantly lower than the 'IFP export' orchards. There were no significant differences in population density between orchard management types. During the remaining three assessments there were no differences in micro-organism populations between the different orchard types, but clear trends of increasing population density from the first to the second assessment in all orchard types and increasing richness in the IFP-orchards. In early spring, the richness in the unconventional orchards was higher than in the conventional orchards, but remained stable throughout the season.

When conventional (all IFP) orchards were compared with unconventional (BIO-GRO and unsprayed) orchards, the richness was higher in the unconventional orchards during the first two assessments, but lower during the last assessment, than in the conventional orchards. The population density was higher in the unconventional orchards only during the first assessment and not different ( $\mathrm{P}>0.05)$ from the other orchards at any other time (Table 4). 
TABLE 4: Mean microbial population density (CFU x10\%/leaf) and richness (RTU/orchard) at the four assessments.

\begin{tabular}{|c|c|c|c|c|c|c|c|c|}
\hline & \multicolumn{2}{|c|}{ Assessment 1} & \multicolumn{2}{|c|}{ Assessment 2} & \multicolumn{2}{|c|}{ Assessment 3} & \multicolumn{2}{|c|}{ Assessment 4} \\
\hline & $\mathrm{CFU}$ & RTU & $\mathrm{CFU}$ & RTU & $\mathrm{CFU}$ & RTU & $\mathrm{CFU}$ & RTU \\
\hline \multicolumn{9}{|l|}{ Management types } \\
\hline BIO-GRO & $18.7 \mathrm{a}$ & $11.3 \mathrm{~b}$ & $92.0 \mathrm{a}$ & $12.8 \mathrm{a}$ & $1212.7 \mathrm{a}$ & $14.8 \mathrm{a}$ & $192.5 \mathrm{a}$ & $14.3 \mathrm{a}$ \\
\hline IFP export & $3.9 \mathrm{a}$ & $6.8 \mathrm{ab}$ & $155.2 \mathrm{a}$ & $9.8 \mathrm{a}$ & $126.5 \mathrm{a}$ & $15.5 \mathrm{a}$ & $177.3 \mathrm{a}$ & $16.7 \mathrm{a}$ \\
\hline IFP local market & $4.4 \mathrm{a}$ & $4.5 \mathrm{a}$ & $164.6 \mathrm{a}$ & $9.2 \mathrm{a}$ & $287.8 \mathrm{a}$ & $16.5 \mathrm{a}$ & $187.7 \mathrm{a}$ & $17.5 \mathrm{a}$ \\
\hline Unsprayed & $10.4 \mathrm{a}$ & $12.5 \mathrm{~b}$ & $150.5 \mathrm{a}$ & $13.0 \mathrm{a}$ & $132.5 \mathrm{a}$ & $16.0 \mathrm{a}$ & $91.8 \mathrm{a}$ & $13.0 \mathrm{a}$ \\
\hline
\end{tabular}

Conventional (all IFP orchards) versus unconventional (BIO-GRO and unsprayed)

Conventional $\quad 4.1 \mathrm{a} \quad 5.7 \mathrm{a} \quad 159.9 \mathrm{a} \quad 9.5 \mathrm{a} \quad 207.1 \mathrm{a} \quad 16.0 \mathrm{a} \quad 182.5 \mathrm{a} \quad 17.1 \mathrm{~b}$

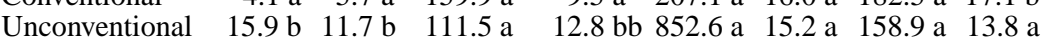

${ }^{1}$ Values in a section within each column sharing the same letter do not differ significantly, ANOVA, $\mathrm{P}<0.05$

\section{DISCUSSION}

In Study 1 the variability in population density and richness during spring was very similar for tree and location within tree effects, while in autumn the location within trees did not contribute at all to the variation. The greatest source of overall variation was between branches and in the replication of samples. It was therefore concluded that in future studies, samples could be collected from any location in the tree but that the numbers of trees per orchard and leaves per tree should be increased to 12 and 10 , respectively.

In Study 2, the method used was sensitive enough to detect differences between conventional and unconventional orchard systems for both population density and richness. However, it did not differentiate between the four orchard management systems, only between conventional and organic management systems, early in the season. This inability to differentiate between all management systems was most likely due to high variation between individual orchards. However, it seems likely that the method would be sufficiently robust for conducting pesticide impact assessments in conventional versus organic management systems, but that assessment timing is crucial with an early spring assessment being recommended.

Few authors have reported on the effect of different orchard management practices on phylloplane micro-organism populations. Pennycook \& Newhook (1981) reported that some yeast species were easily washed from apple leaves by heavy rain. Dix \& Webster (1995) found that the effects of climatic factors and other inhibitory compounds within the atmosphere were variable and complex. In this study, it is expected that the location of orchards relative to local weather patterns, location of trees relative to weather conditions, inoculum sources and leaf wetness or temperature during sampling, may have contributed to the variation between orchards.

Foliar chemical sprays may also affect the phylloplane micro-organism populations. For example, de Jager et al. (2001) found that foliar chemicals reduced size and diversity of populations of bacteria, filamentous fungi and yeasts on mango leaves. RodgersGray \& Shaw (2001) also reported that chlorothalonil reduced microbial populations on wheat leaves. In this study, the sampling programme could not be timed to avoid the fungicide spray applications made by individual growers, as their decisions to spray were often made at short notice, in response to the weather conditions. The high variation found between individual orchards may therefore be attributed to the proximity between sampling and recent spray applications or other management practices. The direct impact of fungicides on phylloplane micro-organism populations or their recovery after spraying 
is not well understood. A study to assess these impacts has been conducted, but analysis of the results has not yet been completed.

It is concluded that differences in culturable phylloplane micro-organism populations between conventional and unconventional orchards in Canterbury can be detected. However, variations within narrower defined orchard management systems were too high to identify significant effects, but this may be overcome by analysing individual organism groups or identifying single species-bioindicators.

\section{REFERENCES}

Blakeman, J.P. 1985: Ecological succession of leaf surface microorganisms in relation to biological control. In: Windels, C.; Lindow, S.E. ed. Biological control on the phylloplane. The American Phytopathological Society, St. Paul, Minnesota. Pp. 6-30.

Bosshard, E.; Schüepp, H.; Siegfried, W. 1987: Concepts and methods in biological control of diseases in apple orchards. Bulletin OEPP/EPPO Bulletin. 17: 655-663.

Dix, N.J.; Webster, J. 1995: Fungal ecology. Chapman \& Hall, London. 549 p.

Goto, M.; Hikota, T.; Nakajima, M.; Takikawa, Y.; Tsuyumu, S. 1994: Occurrence and properties of copper resistance in plant pathogenic bacteria. Annals Phytopath Soc. Japan. 60: 147-153.

Hirano, S.S.; Upper, C.D. 1986: Temporal, spatial and genetic variability of leaf associated bacterial populations. In: Fokkema, N.J.; Van Den Heuvel, J. ed. Microbiology of the phyllosphere. Cambridge University Press, London. Pp. 235-251.

Jacobsen, B.J. 1997: Role of plant pathology in integrated pest management. Ann. Rev. Phytopath. 35: 373-391.

de Jager, E.S.; Wehner, F.C.; Korsten, L; de Jager, E.S. 2001: Microbial ecology of the mango phylloplane. Microbial Ecol. 42: 201-207.

Kinkel, L.L.; Andrews, J.H.; Nordheim, E.V. 1989: Microbial introductions to apple leaves: influences of altered immigration on fungal community dynamics. Microbial Ecol. 18: 161-173.

Morris, C.E.; Monier, J.M.; Jacques, M.A. 1997: Methods for observing microbial biofilms directly on leaf surfaces and recovering them for isolation of culturable microorganisms. Appl. Environ. Microbiol. 63: 1570-1576.

Pennycook, S.R.; Newhook, F.J. 1981: Seasonal changes in the apple phylloplane microflora. N.Z. J. Bot. 19: 273-283.

Rodgers-Gray, B.S.; Shaw, M.W. 2001: The effect of incorporating straw or manure into the soil on the natural microflora of winter wheat. Plant Path. 50: 537-545. 